10

\title{
A Regional Analysis of Enterprise Substitution in Irish Agriculture in the context of a changing Common Agricultural Policy
}

\author{
James A. Walsh \\ Department of Geography, \\ St. Patrick's College, Maynooth
}

\begin{abstract}
In the $1980 \mathrm{~s}$ a number of measures were introduced in order to curb the growing problem of surpluses in production in many sectors of European agriculture. In responding to these measures, farmers have had to reconsider questions of enterprise choice and levels of specialisation in their farming operations. This paper examines the resultant regional patterns of enterprise substitution which have occurred in Ireland. It is demonstrated that, while there has been some continuity between the 1980 s and previous decades in relation to intensification processes, there has been a reversal of the trend towards greater regional specialisation, so that by the end of the 1980s the production system in each region was more diversified. Shift and share analysis is used to disaggregate the components of change for each region.
\end{abstract}

Key Index w'ords: Common Agricultural Policy Reform, Agricultural Change, Ireland

\section{Introduction}

The period from 1960 to the early 1980s was one of rapid modernisation and restructuring of agricultural production in the Republic of Ireland which was associated with increasing specialisation in farming systcms and substantial increases in the scale of each enterprise at farm level. The processes of intensification, specialisation and concentration resulted in pronounced spatial changes (Gillmor, 1987) which to a large extent mirrored the types of adjustments which have occurred among counties in England (Bowler and llbery, 1989), and among regions in the European Community (Bowler, 1985; 1986). Throughout the 1980) the economic policy context within which farmcrs made decisions concerning the level of specialisation and scale of enterprises began to change. The cconomic environment for agriculture is influenced by

lris/h Cicography 24(1) (1991) 10-23, 0075-0078/91/\$03.50

(1) Geographical Society of Ireland, Dublin both macroeconomic processes such as inflation and by adjustments to the Common Agricultural Policy (CAP). Throughout most of the 1980s Irish farmers have had to cope with a severe price-cost squeeze that was largely due to very high levels of domestic inflation and an absence of financial compensation which was related to membership of the European Monetary System (Sheehy, 1988). This price-cost squeeze, which continued until the mid 1980s, resulted in further significant declines in real prices and incomes, and reductions in investment and intensification. In this deteriorating and uncertain economic situation it might also be expected that some farmers would reduce their level of specialisation on enterprises requiring high borrowings over relatively lengthy periods (e.g. store cattle), especially if there were alternative enterprises with more secure levels of return.

At the European Community level there has been an on-going process of reforming the CAP. The background to the adjustments which have taken place was a growing problem of overproduction of certain com- 
Enterprise substitution in Irish Agriculture

modities such as milk, beef and cereals, an increasing reliance on heavily subsidised exports to keenly sought after external markets, and increasing internal pressures to reduce the proportion of its budget expended on agricultural policy. The response to these changing market conditions has been a number of reforms which are designed to make the CAP more market oriented. A number of specific measures have been introduced including quota restrictions on output volumes, a reduction in the level of price supports for products in surplus, the implementation of market stabilising mechanisms which involve limiting the quantities of production for which prices are guaranteed, less openended and more selective use of the intervention system, the extension of co-responsibility levies, a greater emphasis on quality rather than quantity of output, and provision of financial incentives for leaving some land fallow and for afforestation (Commission of the EC, $1985 \mathrm{a}, \mathrm{b} ; 1990)$. The only significant positive measure over this period was the establishment in 1980. of a common market in sheepmeat for the EC which was accompanied by high levels of support for producers through ewe premia which were additional to the headage payments already available to farmers in disadvantaged areas. These support payments were of considerable importance, amounting to approximately half of the estimated value of output from sheep and lamb in 1987 (Fingleton, 1988).

In responding to this changed situation, individual farmers have had to reconsider many of the decisions which had been made over the previous decade or more in relation to choice and scale of enterprises. This has lead to adjustments in the structure of agricultural output. The ability to adjust to the needs of the new market situation is likely to be influenced by several factors, including the size of the farming operation and the comparative advantage/disadvantage of some locations for alternative farming systems. Furthermore, there are a range of demographic factors which may influence a farmer's level of familiarity with, or willingness to learn about, new systems. This paper examines the regional pattern of enterprise substitution in Irish agriculture in the 1980 s, giving particular attention to processes of intensification and diversification. Commencing with a brief overview of trends in production for the entire state, there then follows an examination of the regional pattern of change for each of the main enterprises. Regional deviations are disaggregated into components which reflect the im- portance of the particular combination of farming systems in a region, and the role of other region-specilic factors. The study concludes with a bricf atsessment of future trends and the implications for rural areas. While the adjustments of the 1980 are the main concern. some comparisons with the changes in the 1970) will also be presented where data are compalible.

The main source of data for this analysis is the 1980) agricultural census enumeration and the annual sample survey of farms undertaken by the Central Siatistic:s Office, which covers approximately one-quarter of the agricultural area of the state. These surveys provide data on changes in livestock numbers and landuses for five regions. Additional data relating to the structure of production for individual livestock and crop catcgorics are available from the Farm Structures Surveys which have been undertaken on a biannual basis throughout the 1980s. The latest regional level data from this source is for 1987. While there is a considerable amount of variation within each region, and the accuracy of the data is subject to sampling errors, it is considered to be sufficiently reliable to provide a basis for examining the broad regional adjustments which have occurred. The possibility of a more detailed geographical analysis will not arise until about 1993 when the results of the 1991 agricultural census enumeration become available.

\section{Overall Change 1980-90}

The principal changes at an aggregate level over the 1980s are summarised in Table 1. While the total area used for agriculture declined by approximately $50,(0)(0)$ ha $(0.87 \%)$ there was a decline of over one-fifth $(120,800)$ ha) in the area used for tillage crops. This shift from arable towards grassland more than compensuted for the loss of almost 30,000ha of mostly marginal land to forestry (Lee and McDonald, 1989). The amount of land withdrawn from agriculture in Ireland under cessation or set-aside schemes is very small by comparison with other member states of the EC (Ilbery, 1990)). Among the principal livestock enterprises, there was a decline of approximately 120,000 dairy cows and heifcrs incalf and over 200,000 older beef cattle. These declines: would have released approximatcly $250,(0)(0)$ ha of grassland which have been used to support an increase of about one-third in the number of breeding cows for the beef sector, and a ten percent increase in the number of younger cattle. However, in numerical terms the 
Table 1: Principal changes in agricultural production in the Republic of Ireland $1980-1990$

\begin{tabular}{|c|c|c|c|c|}
\hline & 1980 & 1990 & Absolute change & Percentage change \\
\hline Total agricultural area (000s ha) & 5704.4 & 5654.6 & -49.8 & -0.9 \\
\hline Arca of arable crops (000s ha) & 551.0 & 430.2 & -120.8 & -21.9 \\
\hline Dairy cows \& heifers in calf $(000 \mathrm{~s})$ & 1803.2 & 1684.4 & -118.8 & -6.6 \\
\hline Other cows \& heifers in calf (000s) & 505.1 & 679.8 & +174.7 & +34.6 \\
\hline Callic $0-<1$ year old $(000 s)$ & 1611.2 & 1690.8 & +79.6 & +4.9 \\
\hline Caltle I - <2 years old (000s) & 1562.5 & 1728.4 & +165.9 & +10.6 \\
\hline Caltle 2 ycars old and over $(000 \mathrm{~s})$ & 1413.4 & 1206.2 & -207.2 & -14.7 \\
\hline Ewcs \& rams for breeding (000s) & 1586.1 & 4341.0 & +2754.9 & +173.7 \\
\hline Other sheep $(00) \mathrm{s})$ & 1705.4 & 4355.3 & +2650.1 & +155.4 \\
\hline Horses and ponies $(000$ s) & 68.5 & $51.7 *$ & -16.8 & -24.5 \\
\hline Total pigs $(000)$ & 1030.5 & $995.7 *$ & -34.8 & -3.4 \\
\hline Total poultry $(000)$ & 9903.3 & $8496.1 *$ & -1407.2 & -14.2 \\
\hline
\end{tabular}

Nole: The data for 1990 are based on a postal survey conducted by the Central Statistics Office of over 13,000 farms which are sclected via a stratified sampling process. The 1980 data are from a complete census enumeration.

* these data refer 101989 since none are yet available for 1990 .

Tiable 2a: Absolute changes in structure of agricultural production by region, 1980-1989.

Midlands Southeast Southwest West Northwest Ireland \& East

\begin{tabular}{|c|c|c|c|c|c|c|}
\hline Arable crops (000)s ha) & -29.7 & -41.7 & -25.7 & -15.0 & -9.0 & -121.1 \\
\hline Dairy cows \& heifers in calf $(000 \mathrm{~s})$ & -4.0 & -37.3 & -58.2 & -28.7 & -27.9 & -156.0 \\
\hline Other cows \& heifers in calf $(000 \mathrm{~s})$ & 11.9 & 19.5 & 29.2 & 32.4 & 17.5 & 110.6 \\
\hline Callule 0 - 2 yrs $(000 \mathrm{~s})$ & 49.4 & 55.9 & 48.3 & -11.4 & 1.1 & 143.5 \\
\hline Catlle $>2$ yrs old $(000 \mathrm{~s})$ & -39.9 & -49.3 & -48.4 & -47.7 & -21.8 & -207.2 \\
\hline Sheep $(00)$ s) & 708.4 & 1300.5 & 586.3 & 1113.3 & 698.0 & 4406.3 \\
\hline
\end{tabular}

Tablc 2b: Percentage changes in structure of agricultural production by region, 1980-1989.

Midlands Southeast Southwest West Northwest Ireland \& East

Arable crops (00)s ha)

Dairy cows \& heifers in calf $(000 \mathrm{~s})$

Other cows \& heifers in calf (000s)

Caltle ()-2 yrs (000)s)

Callle $>2$ yrs old $(000 \mathrm{~s})$

Sheep (0)( $)$ s)

$\begin{array}{rr}-17.0 & -20.0 \\ -1.9 & -8.3 \\ +15.3 & +21.9 \\ +9.1 & +7.9 \\ -10.3 & -16.4 \\ +173.6 & +148.1\end{array}$

-24.3
-8.0
+46.3
+7.3
-19.9
+135.8

-45.0
-13.9
+20.5
-1.5
-15.7
+104.4

$-28.7$

$-13.6$

$+14.9$

$+0.2$

$-12.2$

$+137.5$

$-21.9$ 


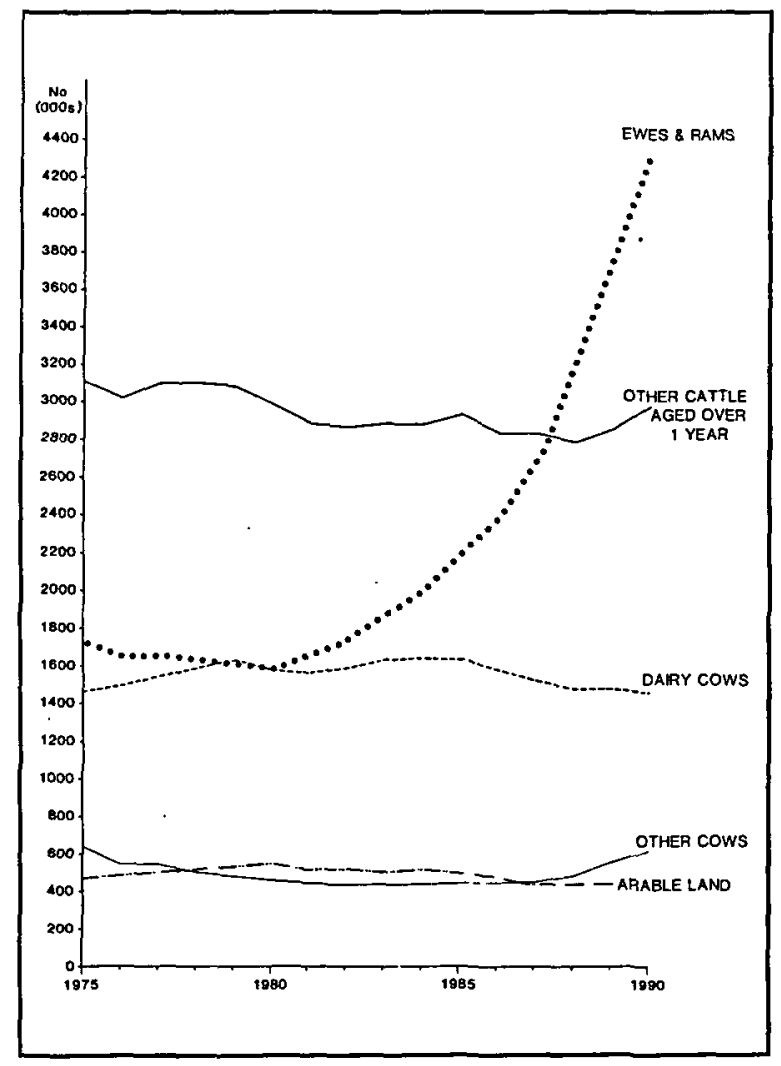

Figure 1:Trends in main agricultura] enterprises 1975-1990

most dramatic change has been in relation to sheep, with the total number of ewes and rams for breeding increasing by almost $174 \%$. The main factors responsible for this "sheep rush" in the 1980 s were the production constraints on the more profitable alternative enterprises and the relatively poorer returns from the other major competing enterprises (Fingleton, 1988).

Figure 1 traces the changes on an annual basis for the main categories of livestock and the arable area between 1975 and 1990. (For some items it is not possible to make direct comparisons between the 1970 census data and that collected for later dates). Up to 1980 the number of dairy cows and the area under arable crops (mostly cereals) expanded under the influencc of significant levels of price support from the CAP, while the numbers of other cattle (including breeding stock for the beef sector) and sheep continued to declinc. The first half of the 1980s was a period of relative stibility apart from the increase in the number of sheep following the introduction of market stabilising measures and producer supports in 1980. The number of dairy cows increased gradually to a peak of 1.64 million in 1984. At this stage arable production was becoming more and more restricted to large farms in the East and Southeast which benefitted most from economies of scale and comparative advantage in relation to both soils and climatic conditions (Gardiner and Radford, 1980; Keane. 1986). Dairying was expanding outwards from the corc region of production in the Southwest to parts of the Southeast and the Midlands. These patterns have been established as outcomes from the modernisation which occurred over the previous two decades (Walsh, 1986) and have been mapped in detail by Horner ct al. (1984). The number of sheep had been declining since the mid 1960s and their spatial distribution was increasingly

Table 3: Change in the structure of cereals production 1980-87

\begin{tabular}{|c|c|c|c|c|c|c|}
\hline \multirow[b]{3}{*}{ Area grown (ha) } & \multicolumn{3}{|c|}{ Midlands \& East and Southeast } & \multicolumn{3}{|c|}{ Remainder of the State } \\
\hline & \multicolumn{6}{|c|}{ Number of Farms (000s) } \\
\hline & 1980 & 1987 & $\%$ change & 1980 & 1987 & $\%$ change \\
\hline$<2.0$ & 6.2 & 2.6 & -58.1 & 31.9 & 13.0 & -59.2 \\
\hline $2-5.0$ & 9.0 & 5.3 & -48.9 & 7.1 & 4.7 & -33.8 \\
\hline $5-10.0$ & 5.4 & 3.7 & -31.5 & 3.0 & 2.0 & -33.3 \\
\hline$>10.0$ & 8.3 & 6.1 & -26.5 & 2.6 & 1.9 & -26.9 \\
\hline Total & 28.9 & 17.7 & -38.8 & 44.6 & 21.6 & -51.6 \\
\hline Average area per farm & 10.3 & 12.3 & 19.4 & 2.7 & 3.7 & +37.0 \\
\hline
\end{tabular}


restricted to upland areas as more profitable enterprises were substituted on dry lowlying grazing lands. The effects of recent CAP reforms measures since the mid 1980s are evident from the decline in the number of dairy cows and in the area under arable crops. Over the same period there has been almost a doubling of the number of sheep.

\section{Adjustments at regional level}

It is against the background outlined above that one must consider the adjustments which have occurred at regional level. The regional framework adopted here is that used by the Agriculture and Food Development Authority, Teagasc, since these are the only units for which comparable data are available (Figure 2). The locational patterns established by the main enterprises in Irish agriculture in the 1960s and 1970s have already been described by Horner et al. (1984) and Gillmor (1987). The absolute and percentage level changes for each of the main enterprises in each region between 1980 and 1989 are summarised in Table 2. The decline in arable farming was greatest in absolute terms in the Southeast, where in 1980 almost $38 \%$ of all the arable farming in the state was concentrated. In relative terms the most significant decline was in the West where the total area was almost halved. Overall, the data confirm the continuation of a trend towards increasing concentration on to fewer farms in the eastern half of the state, as indicated for cereals which account for almost $80 \%$ of the total arable area (Table 3). The contrasts in scale

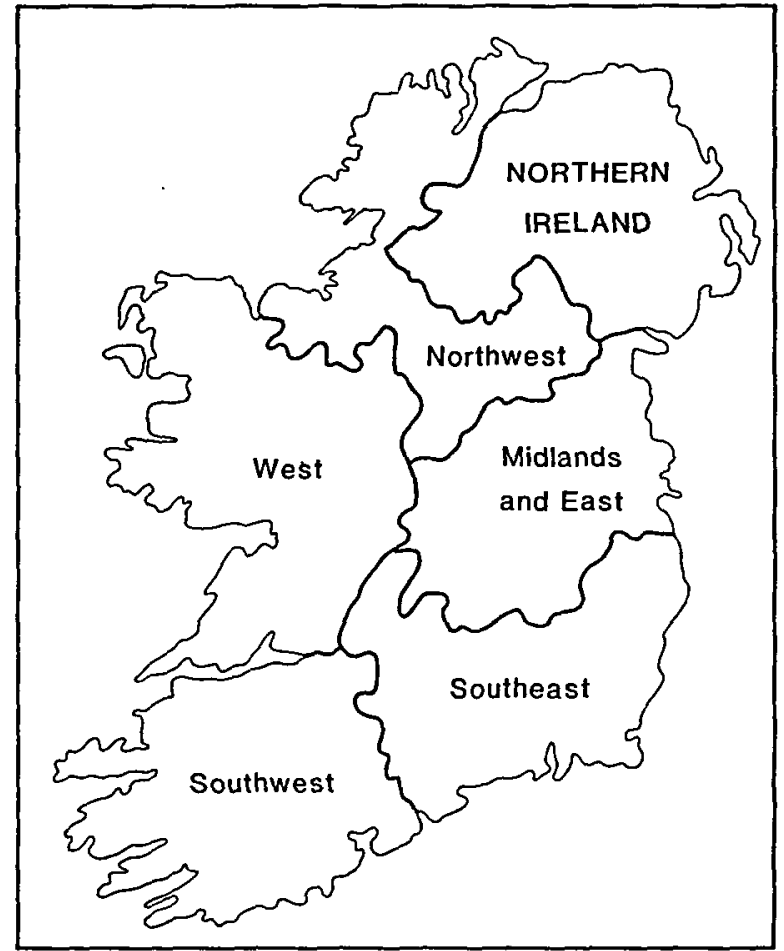

Figure 2: Agricultural regions as defined by Teagasc

of production between the eastern and western regions resulted in a decline of almost $52 \%$ in the number of farms with cereals in the western regions compared with a decline of $39 \%$ for the eastem regions. The combined share of the total arable production located in the Midland and East and Southeast increased from

Table 4: Restructuring of milk production 1983-88

\begin{tabular}{|lcccccc|}
\hline & \multicolumn{3}{c}{ Number of Suppliers (000s) } & \multicolumn{3}{c|}{ Percentage of Milk Supplies } \\
$\begin{array}{l}\text { Size category } \\
\text { (00) gallons) }\end{array}$ & 1983 & 1986 & 1988 & 1983 & 1986 & 1988 \\
& & & & & & \\
$<15$ & 40.4 & 33.1 & 26.8 & 25.6 & 21.5 & 19.1 \\
$15-30$ & 12.4 & 12.2 & 12.7 & 27.0 & 26.0 & 27.7 \\
$30-60$ & 7.1 & 7.6 & 7.6 & 29.6 & 31.3 & 32.1 \\
$>60$ & 2.1 & 2.5 & 2.4 & 17.7 & 21.2 & 20.9 \\
Total & 62.0 & 55.4 & 49.5 & 100.0 & 100.0 & 100.0 \\
& & & & & & \\
\hline
\end{tabular}

Source: Agriculture and Food Policy Review, 1990. 
$60.8 \%$ in 1970 to $69.2 \%$ in 1980 and to $72.1 \%$ in 1989 .

The effects of cutbacks in dairying were most serious on the smaller farms, many of which were no longer able to provide an adequate income because of restrictions on expansion and the extra costs associated with producing milk to ever-increasing quality specifications. The introduction of milk quotas in 1984 has accelerated the structural changes which had been taking place since the early 1970 s. It has been estimated that over the period 1970-83 the annual decline in the number of manufacturing milk producers was $3.3 \%$, while between 1983 and 1988 the annual rate increased to $4.4 \%$ (Agriculture and Food Policy Review, 1990). There was a decline of one-third between 1983 and 1988 in the number of dairy farms producing less than 15,000 gallons of milk (Table 4). Over the same period the number of suppliers in the over 30,000 gallons category increased from about 9,200 to 10,000 with their share of total supplies increasing from $47.3 \%$ to $53 \%$. The number of herds with fewer than 10 cows decreased from 52,000 in 1980 to 24,000 in 1987 . Since the average herd sizes in the West and Northwest in 1980 were only 6.9 and 8.5 the overall declines in the numbers of dairy cows and heifers-in-calf in these regions reached almost $14 \%$. The decline among small scale producers was assisted by a cessation scheme operated by the Department of Agriculture to encourage farmers to switch to alternative enterprises. The decline in the numbers of dairy cattle in the western regions would have been greater if the Department of Agriculture had not imposed limits on the operation of the cessation scheme in these regions. By contrast, in the Midlands and East where farms are much larger and where there is an extensive liquid milk trade there was a significant increase up to 1984 , followed by a decline of only $8 \%$ (Table 5 ). In this region the average herd size increased from 17.5 to 27.2 cows between 1980 87. Over the same period the average herd sizes in the Southeast and Southwest increased to 33.3 and 28.5 cows respectively. While the core Southwest region accounted for over $37 \%$ of the total decline it nevertheless marginally increased its share of the total dairy herd from $39.7 \%$ to $40.5 \%$

One of the responses to the decline in dairying was an expansion in the number of cows that are retained to provide calves for the beef sector. In some situations small scale dairy producers were offered incentives in order to encourage an expansion of the suckler herd and so maintain the supply of calves to the beef cattle sector. This pattern of enterprise substitution appears to have been most important in the Southwest (Table 2) which was the only region where the number of farms with non-dairy cows increased up to 1987 . Over $80 \%$ of the increase of almost 30,000 in the number of suckler cows has taken place on farms with fewer than 10 cows. The very high level of expansion in the Southwest (46.3\%) was probably mainly due to a combination of a high level of decline in the number of small scale dairy farms and a much lower rate of expansion of sheep in this region by comparison with the experience in the Midlands and Southeast regions. The fact that the level of expansion in the core regions for this farming system, in the West and Northwest, was only $18.1 \%$ compared with $26.5 \%$ in the remainder of the state is a reflection of the range of constraints on expansion in these regions. These include not only the very small size of many farms but also factors such as management difficulties associated with keeping suckler cows and

Table 5: Change in number of dairy cows and heifers in-calf 1980-89

\begin{tabular}{|lccccrr|}
\hline & \multicolumn{3}{c}{ Number (000s) } & \multicolumn{3}{c|}{ Percentage Change } \\
& 1980 & 1984 & 1989 & $1980-84$ & $1984-89$ & $1980-89$ \\
Midlands \& East & 213.8 & 228.3 & 209.8 & +6.8 & -8.1 & -1.9 \\
Southeast & 451.3 & 470.0 & 414.0 & +4.1 & -11.9 & -8.3 \\
Southwest & 726.0 & 729.0 & 667.8 & +0.4 & -8.4 & -8.0 \\
Northwest & 207.1 & 209.0 & 178.4 & +0.9 & -14.6 & -13.9 \\
West & 205.1 & 206.3 & 177.2 & +0.6 & -14.1 & -13.6 \\
Ireland & 1803.3 & 1842.6 & 1647.2 & +2.2 & -10.6 & -8.7 \\
\hline
\end{tabular}


in some instances demographic considerations such as old age. One survey in 1987 found that $72 \%$ of nondairy farmers who were either reducing or not expanding their suckler herds would not be induced to "keep extra suckler cows under any perceived change in circumstances" (Hickey and Connolly, 1987). Unlike the dairy sector where there has been an increase in the size of herds there has been very little structural change in the beef cow sector with $83 \%$ of herds having less than 10 cows in 1987. This basic structural problem is accentuated when it is accompanied low-cost lowoutput production systems that result in the majority of drystock farms being unable to provide a viable income for a farm family (Heavey et al., 1981).

Among the remaining categories of cattle there was a steady decline in the number of animals aged over two years which was partially offset by increases in the number of younger cattle. The decline in the first half of the decade was associated mostly with the increase in dairying from which the average gross margin per hectare was usually two to three times greater than from cattle systems. In latter years returns from sheep farming have been considerably better than from most cattle systems, encouraging an expansion of sheep on land formerly used for beef cattle (Teagasc, 1986; 1990). The decline of almost $15 \%$ in the number of older cattle is probably due to a number of factors including improvements in production systems such as better feeding programmes, adoption of grading standards by meat processors which favour younger cattle, and possibly high interest charges which were a feature of most of the 1980 s. The ratio of cattle aged over two years to the number aged between one and two years has declined steadily from a peak of 0.92 in 1977 to 0.72 in 1990 . Among regions the decline in older cattle was greatest at $20 \%$ in the Southwest where their role in the livestock economy is least. By contrast, in the Midlands core region for this category of livestock, where they accounted for over $37 \%$ of all livestock units in 1980 , the decline was only about $10 \%$. This pattern of adjustment, therefore, suggests a retreat from the more marginal farms and regions and greater concentration into the core areas.

The pattern of change in relation to younger cattle exhibits a major contrast between the West and Northwest as regions of stagnation in contrast to expansion elsewhere. This contrast may be partly related to the indirect effects of quota restrictions on dairy farms. Traditionally, there has been a significant level of trade in calves between the dairy farms of the southwest and suckler herds and young catle producers in the west and northwest. As noted already some dairy farmers in the southwest have changed to suckler systems and are therefore purchasing some calves from local dairy farmers. Furthermore, it is likely that in response to restrictions on herd expansion some dairy farmers are retaining their calves for longer periods. Between 1984 and 1989 the number of calves increased by only $24,000(1.5 \%)$ but the share of the total in the West declined from $22.8 \%$ to $20.2 \%$ while in the Southwest the share increased from $23.1 \%$ to $25.1 \%$. Thus, apart from encouraging enterprise substitution the changing market and policy conditions may also have contributed to a disruption of long established inter-regional livestock trading patterns.

The expansion in the number of sheep in the 1980s

Table 6: Change in number of livestock units by region, 1970-1989

\begin{tabular}{|lrrrrrr|}
\hline & \multicolumn{3}{c}{ Total Livestock Units (000s) } & \multicolumn{3}{c|}{ Percentage Change } \\
& 1970 & 1980 & 1989 & $1970-80$ & $1980-89$ & $1980-89 *$ \\
& & & & & & \\
Midlands \& East & 994.5 & 1028.1 & 1148.9 & +3.4 & +11.8 & +12.7 \\
Southeast & 1173.3 & 1334.0 & 1513.5 & +13.7 & +13.5 & +11.2 \\
Southwest & 1208.6 & 1406.4 & 1443.8 & +16.4 & +2.7 & +3.2 \\
West & 1124.2 & 1217.2 & 1355.6 & +8.3 & +11.4 & +12.6 \\
Northwest & 722.7 & 826.3 & 908.8 & +14.3 & +10.0 & +9.7 \\
& & & & & & \\
Ireland & 5223.3 & 5812.0 & 6370.6 & +11.3 & +9.6 & +9.6 \\
\hline
\end{tabular}

* changes which take account of adjustments in the area of land devoted to livestock 
Table 7: Composition of total livestock units 1980 (A) and 1989 (B) by region

\begin{tabular}{|c|c|c|c|c|c|c|c|c|c|c|c|c|}
\hline & \multicolumn{2}{|c|}{$\begin{array}{l}\text { Midlands } \\
\text { \& East }\end{array}$} & \multicolumn{2}{|c|}{ Southeast } & \multicolumn{2}{|c|}{ Southwest } & \multicolumn{2}{|c|}{ West } & \multicolumn{2}{|c|}{ Northwest } & \multicolumn{2}{|c|}{ Ireland } \\
\hline & A & B & A & B & A & B & A & B & A & B & A & $\mathrm{B}$ \\
\hline $\begin{array}{l}\text { Dairy cows \& } \\
\text { heifers in calf }\end{array}$ & 19.8 & 17.6 & 32.4 & 26.5 & 49.8 & 44.8 & 16.5 & 12.8 & 24.2 & 19.1 & 29.9 & 25.1 \\
\hline $\begin{array}{l}\text { Other cows \& } \\
\text { heifers in calf }\end{array}$ & 6.6 & 6.9 & 5.9 & 6.2 & 3.9 & 5.6 & 11.5 & 12.4 & 12.6 & 13.2 & 7.7 & 8.5 \\
\hline Cattle $0-2$ years & 27.3 & 27.0 & 26.4 & 25.1 & 22.3 & 23.0 & 31.3 & 28.4 & 30.2 & 27.1 & 27.1 & 26.0 \\
\hline Cattle $2+$ years & 37.6 & 30.2 & 22.5 & 16.6 & 17.3 & 13.5 & 24.9 & 18.9 & 21.7 & 17.3 & 24.3 & 18.9 \\
\hline Sheep & 6.7 & 16.9 & 11.1 & 24.3 & 5.2 & 12.0 & 14.7 & 26.8 & 10.5 & 22.8 & 9.6 & 20.5 \\
\hline $\begin{array}{l}\text { Diversification } \\
\text { Index }\end{array}$ & 0.61 & 0.65 & 0.64 & 0.66 & 0.55 & 0.60 & 0.67 & 0.67 & 0.67 & 0.67 & 0.64 & 0.67 \\
\hline
\end{tabular}

Totals do not add to $100 \%$ since the livestock unit equivalents for horses and ponies as well as bulls are not included.

*The diversification index is computed according to the entropy formula (Aitchison, 1984)

has been discussed by Walsh (1989). Of critical importance in this area was the establishment of a common market in sheepmeat for the European Community in 1980 which restored confidence to this sector and made it an economically attractive enterprise for substitution on farms where some of the more established enterprises were subject to restrictions. Between 1981 and 1989 the number of farmers with a sheep enterprise increased from 45,000 to an estimated 54,000 and the average herd size doubled from 54.4 to 107.2 (Agriculture and Food Policy Review, 1990). The bulk of the expansion occurred in the late 1980 s on cattle farms and smaller dairy farms. This was especially true of dry low lying areas, leading to an increase in the proportion of the total flock located in the Midlands and East and Southeast regions from $39 \%$ in 1980 to almost $43 \%$ in 1989 , while over the same period, despite a very considerable absolute increase (Table 2), the West region's share declined from $32.4 \%$ to $28.3 \%$. Expansion in upland parts of the latter region is severely restricted by limitations of the physical environment which in some areas resulted in reports of overgrazing and local conflicts over access to commonage lands. The much lower levels of expansion in the Northwest and Southwest reflect not only the constraints imposed by farm size but also the lack of a tradition of sheep rearing in many parts of these regions which is partly due to unsuitable ecologial conditions (Gillmor, 1977).

A more accurate assessment of the extent of substitution and intensification in each region requires that all categories are converted into livestock unit equivalents (LUEs) ${ }^{1}$. The total increase of almost 560,000 in the number of LUEs over the period 1980-1989 was the net outcome of an increase of some 920,000 LUEs of sheep ( $81.2 \%)$, suckler cows ( $10.5 \%)$ and young cattle (8.3\%) and a decline of approximately 365,000 LUEs of older cattle (56.8\%), dairy cows (38.6\%) and horses (4.6\%). Increases varied between $10 \%$ in the Northwest and $13.5 \%$ in the Southeast, apart from the Southwest where the increase was only $2.7 \%$. This pattern of change contrasts remarkably with the pattern established in the 1970s when the total increase in LUEs was not much different (Table 6). In the 1970s the highest growth rate was in the Southwest largely due to the intensification of dairying while the lowest was in the Midlands and East due to an expansion of commercial tillage farming (Homer et al., 1984). When account is taken of the changes in the area of land devoted to livestock rearing in each region it is evident that the greatest expansion was in the Midlands \& East $(12.7 \%)$, (Table 6). A comparable level of expansion was achieved in the West, even though the average livestock density per hectare in the region is approximately $20 \%$ less than in the Midlands \& East. 
Table 8 : Percentage distribution of pigs and poultry by region

\begin{tabular}{|c|c|c|c|c|c|c|}
\hline & \multicolumn{3}{|c|}{ Pigs } & \multicolumn{3}{|c|}{ Poultry } \\
\hline & 1970 & 1980 & 1989 & 1970 & 1980 & 1989 \\
\hline Midlands \& East & 14.2 & 14.0 & 13.1 & 19.4 & 14.0 & 10.9 \\
\hline Southeast & 24.3 & 29.3 & 29.1 & 15.6 & 14.3 & 15.2 \\
\hline Southwest & 31.3 & 25.4 & 25.4 & 20.5 & 27.6 & 28.0 \\
\hline West & 9.1 & 4.6 & 4.0 & 14.7 & 6.4 & 3.6 \\
\hline Northwest & 21.1 & 26.6 & 28.4 & 29.7 & 37.8 & 42.2 \\
\hline Ireland & 100.0 & 100.0 & 100.0 & 100.0 & 100.0 & 100.0 \\
\hline
\end{tabular}

The composition of the total livestock units for each region in 1980 and 1989 is set out in Table 7 which demonstrates in particular the dominance of dairying in the Southwest. The extremely high level of expansion in sheep is reflected in the doubling of its share of total LUEs so that it is more important than older cattle in all regions apart from the Midlands and East, and it has overtaken the role of dairying in the Northwest. As might be expected the high level of enterprise substitution in all regions has resulted in more diversified production systems, especially in the Southeast and Midlands \& East regions (Table 7).

The rationalisation of the pig and poultry sectors continued (Table 8). The number of holdings with a pig rearing enterprise declined from just over 10,000 in 1981 to 2,500 in 1989. This adjustment was accompanied by a fourfold increase in the average size of pig herds to approximately 400 animals. The top $10 \%$ of pig herds now account for approximately $80 \%$ of the total breeding herd. The extent of regional change in the pig sector was less than in the 1970s reflecting the extent to which a relatively small number of producers had achieved a position of dominance in this sector by the early 1970 s. In the poultry sector the total flock declined by over $14 \%$ compared with a decline of under $12 \%$ for the 1970 s. In this sector there was a further increase in the level of concentration in the Northwest region (mostly county Monaghan) mainly due to declines in the share of the Midlands and East and West regions (Table 8). The shares of the southern regions remained virtually unchanged.

The overall impact of the many factors affecting the regional patterns of change in the levels of localisation of each enterprise are summarised in Table 9. Following Gillmor (1987) regional localisation coefficients have been computed for each enterprise for 1970,1980 and $1989^{2}$. The coefficients range between zero and unity with values of zero indicating that the enterprise was distributed amongst the regions in exactly the same proportions as the agricultural land. The data in Table 9 confirm that there has been an increase in the level of localisation of arable crops, and the pig and poultry sectors. In each case the increase in localisation has been less than in the preceeding decade. In the case of dairying there has been a very small increase in localisation as the enterprise has retreated from the more marginal areas. By contrast there has been a slight reduction in the coefficient for suckler cows. Not surprisingly, the most significant reduction was in relation to sheep as that enterprise expanded and diffused through all regions. The reduction in localisation in the 1980 s continued a trend established in the 1970 s under different circumstances when the total number of sheep declined by almost one-fifth. Thus between 1970 and 1989 the share of the total flock located in the West and Northwest regions declined from $52 \%$ to $44 \%$.

\section{Shift and Share Analysis}

The sources of the differential patterns of change between the regions in the number of livestock units can be examined further using the technique of shift and share analysis, (Higgins, 1978; Bowler, 1981), which allows for the disaggregation of the total change in the number of livestock units in each region into three components: (a) a national component giving the change that would have occurred if the aggregates for all livestock categories in each region changed at the same rate, assuming the area of land devoted to livestock 
Table 9: Localisation coefficients by region for major farming enterprises, 1970, 1980 and 1989.

\begin{tabular}{|llcc|}
\hline & \multicolumn{3}{c|}{ Localisation coefficient } \\
& 1970 & 1980 & 1989 \\
Arable crops & & & \\
Dairy cows and heifers in calf & 0.214 & 0.319 & 0.346 \\
Other cows and heifers in calf & n.a. & 0.221 & 0.223 \\
Other cattle aged over 1 year & n.a. & 0.144 & 0.127 \\
Sheep & 0.091 & 0.073 & 0.083 \\
Total livestock units & 0.172 & 0.151 & 0.126 \\
Pigs & 0.047 & 0.050 & 0.045 \\
Poultry & 0.124 & 0.213 & 0.226 \\
\hline
\end{tabular}

remained unchanged, (b) a structural component reflecting the change due to the mix of livestock categories in the region and the trends in each category in relation to overall national trends, and (c) a competitive component giving the change that can be attributed to specific regional factors which result in deviations from the overall trend for each livestock category. These components are usually referred to as the Regional share $(\mathrm{R})$, the Proportional shift $(\mathrm{P})$ and the Differential shift $(R)$ respectively. The sum of the proportional and differential shifts represents the net shift in each region.

The components of the changes in livestock numbers are presented in Table 10. A complicating factor which is not taken into account in the shift and share analysis is the amount of change due to adjustments in the area of land devoted to livestock. By calculating the change in the number of hectares devoted to livestock and applying livestock density ratios one can estimate for each region the expected increase/decrease in livestock units. These are presented in the final column of Table 10 and should be considered as part of the regional share. The total positive net shift amounted to almost 98,000 livestock units, which represents $17.5 \%$ of the total increase.

The largest increase was almost 180,000 LUEs in the Southeast, of which $17 \%$ was due to an increase of over $22,000 \mathrm{ha}$ of land devoted to livestock. This is the only region where both the proportional and differential shift components were positive. The proportional shift was mainly due to an above average concentration on sheep and a below average dependence on the fattening of older cattle, while the differential factor was mostly related to the fact that the region has the largest pro- portion of holdings greater than $40 \mathrm{ha}$ in size (Walsh and Horner, 1984) and the most favourable soils and climatic conditions (Gardiner and Radford, 1980; Keane, 1986). Since the dairy herds in the region are on average larger than in the other regions there was less restructuring and therefore a smaller level of decline in dairy cattle than might have been expected (Table 5). About twothirds of the differential shift component was due to the expansion of sheep, a large part of which probably took place on dairy farms which resulted in a very efficient use of grassland because of the different grazing habits of both types of livestock.

After the Southeast the next largest net shifts occurred in the Midlands \& East and West where they contributed just over $18 \%$ and $15 \%$ of the total increases respectively. However, the structure of the net shifts differed between the two regions. The Midlands \& East had by far the largest positive differential shift component which is related to the high proportion of large farms on land with either a wide or moderately wide use range. Some of the dairy farmers in the region also benefit from access to the large market for liquid milk in the Greater Dublin area which tends to provide higher returns for its suppliers and is also characterised by a different seasonality pattem. These were probably very important contributory factors to the very high level of expansion of dairying in the early 1980s (Table 5) and the relatively low level of decline since 1984. Farmers supplying milk to dairies serving the liquid milk market are probably the least likely group to switch to alternative enterprises. Consequently the decline in the number of dairy cows and heifers in-calf was less than a quarter of the level in the state as a whole. The significant positive differential shift was 
counterbalanced by a large negative proportional shift which resulted mostly from the dominance of store cattle fattening as an enterprise and the under representation of sheep farming in the early 1980 s (Table 7). The decline of over $6500 \mathrm{ha}$ of land devoted to livestock resulted in approximately 8800 fewer LUEs in 1989.

In the West region there was a very significant proportional shift, almost equivalent to the regional share component, which can be associated with its very high levels of specialisation on sheep farming and the rearing of young cattle. However, the severe limitations of small farm sizes coupled with a poor land resource base resulted in a strong negative differential shift, of which over three-fifths was due to the less than expected increase in sheep numbers. When the shift components are related to the total number of livestock units for 1980 it is noteworthy that the relative magnitude of the components for the Midlands \& East and West regions are almost identical, but, of course, with opposing signs (Table 10). In this region the loss of some 12,500 ha of land devoted to livestock meant that the number of LUEs in 1989 was approximately 13,000 (9.4\%) fewer than it might have been.

Among the remaining regions, the pattern of change in the Northwest was rather similar to that in the West though the relative scale of the components was much smaller reflecting the lesser role of sheep and young cattle in this very diverse region, which includes an important concentration on dairying in counties Cavan and Monaghan. The Southwest was the only region in the 1980 s with a negative net shift. The negative proportional shift of over 104,000 livestock units was equivalent to a loss of $7.4 \%$ of the 1980 total of livestock units. The source of this component was undoubtedly the very high level of dependence on dairying which accounted for almost half of the livestock units in 1980, and the very minor role of sheep production (Table 7). The lack of complementarity between sheep and dairying in these areas, unlike the situation that prevails in parts of the Southeast, can be related to differences in soil conditions with the poorly drained gley soils of parts of Limerick and north Kerry contributing to a higher susceptabilty to diseases and lower weight gains among sheep. The differential shift component contributed an increase of only $0.4 \%$ in the number of livestock units. The decline of over $6000 \mathrm{ha}$ of land devoted to livestock reduced the overall increase by approximately $20 \%$.

In summary, the analysis in this section has pinpointed large differences between the eastern and western regions, with very pronounced differential shift components in both the Midlands \& East and the West, while there are significant proportional shift components in both the Southwest and West. The Midlands \& East and Northwest represent the extremes in competitiveness (Bowler, 1981). The Southeast benefits from having both positive proportional and differential components, while in the Northwest the opposite is the case with components of somewhat larger magnitude cancelling each other out. It should be noted that there are important local variations within each region as evidenced on the one hand by problems

Table 10: Shift and Share components of change 1980-89 in total number of livestock units by region.

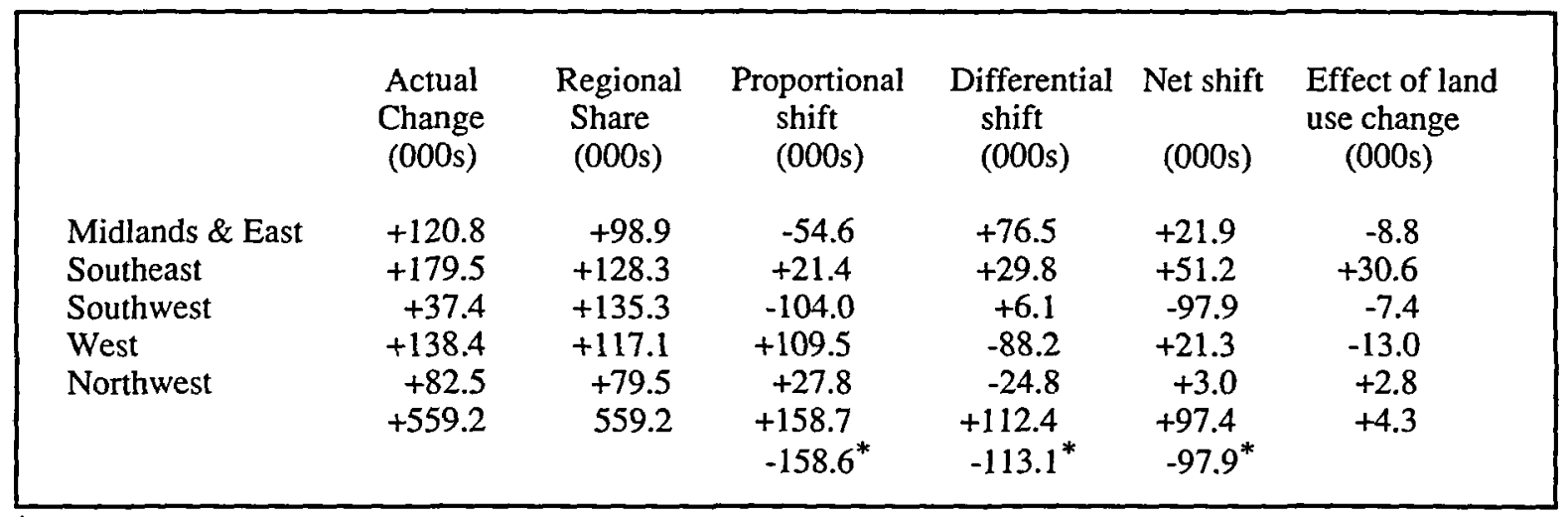

* discrepancies between positive and negative totals due to rounding errors. 
relating to low incomes and living standards on small farms in Wexford (Irish Farmers Association, 1989), while on the other hand in the Northwest region some farmers in county Monaghan have very quickly responded to the need for diversification by becoming involved in a locally organised mushroom growing industry.

\section{Discussion}

Over the past two decades agricultural production in Ireland has been characterised by very high levels of temporal volatility in relation to output and incomes, mainly as a result of differences between Ireland and other EC member states in relation to key macroeconomic factors (Sheehy, 1988). The objectives and operation of the Common Agricultural Policy have been revised in an attempt to orientate production away from the open-ended support-led arrangements of the 1970 s to a more controlled and market-led system. This process of reform of the Common Agricultural Policy is on-going and likely to become much more significant in the years ahead (McSharry, 1991). The reform process affects different sectors in different ways, which in turn results in differential regional impacts. The preceeding analysis has demonstrated the uneven regional impacts on livestock enterprises of reform measures devised for particular sectors of agriculture in the European Community. While some continuity may be observed between the recent trends and those of the 1970s and early 1980 s the imposition of restrictions on the volume of output from milk, has resulted in a reversal of the trend towards greater regional specialisation and led to an increase in diversification. The types of responses within particular regions to the changing circumstances have varied according to the structure of agriculture prior to the introduction of the new measures, the possibilites for scale economies and the strength of local factors of comparative advantage/disadvantage. In this regard the experience in the Southwest in particular differed greatly between the two decades.

While throughout the 1980s there has been more intensification, there has also been a shift to greater reliance on categories of livestock which yield lower economic returns than the dairying sector. This form of enterprise substitution, which is heavily dependent on the very high levels of support payments for sheep, is likely to increase the extent of marginalisation (Kelleher and O'Mahony, 1984) and the disparities between regions (Gillmor, 1989; Walsh, 1986). There are already significant disparities in farm household incomes which can be related to variations in size of farm and farm business, farming systems, efficiency levels, demographic structure and opportunities for additional non-farm based income. Changes in the structure of production and in the relative importance of different enterprises in each region have probably altered the regional distribution of farm incomes. These differences require a variety of policy responses, some of which have recently been identified in a major review undertaken by the Department of Agriculture and Food. Already the government has declared that its priority is to maintain "the maximum number of full-time commercially-viable family farm units". Where this objective cannot be achieved the main task is to "stabilise the rural population by appropriate integration of agricultural, industrial and other policies" (Government of Ireland, 1991). These policy objectives are in accordance with the increasing emphasis in the EC on rural development which focusses more on non-agricultural sources of development in rural areas (Commission of the EC, 1988). While there are many problems involved in diversifying the economic base of rural areas (Conway and O'Hara, 1987; Conway, 1990; An Taisce, 1990) the experience of the last decade demonstrates that this is urgently required and, furthermore, that greater attention needs to be given to the links between diversification and regional adjustment.

\section{Notes}

1 Livestock unit equivalents have been calculated from the Central Statistics Office data on the basis of the coefficients identified by Attwood and Heavey (1964) and those used by An Foras Taluntais in their Farm Management Surveys.

2 The localisation coefficient is obtained by calculating for each region the difference between its percentage share of a particular enterprise and its percentage share of the total agricultural area in the state. All the positive deviations are added and their sum is divided by 100 to give the coefficient of localisation for the particular enterprise. 


\section{References}

AGRICULTURE AND FOOD POLICY REVIEW GROUP (1990) Agriculture and Food Policy Review, Dublin.

AITCHISON, J. W. (1984) Coefficients of specialisation and diversification: employment in rural France, Area, 16(2), 121-129.

ANTAISCE (1990) Forestry in Ireland:policy and practice, An Taisce, Dublin.

ATTWOOD, E. A. and HEAVEY, J. F. (1964) Determination of grazing livestock units, Irish Journal of Agricultural Research, 3, 249-51.

BOWLER, I. R. (1981) Regional specialisation in the agricultural industry, Journal of Agricultural Economics, 32, 43 -54.

BOWLER, I. R. (1985) Agriculture under the Common Agricultural Policy: a geography, University of Manchester Press, Manchester.

BOWLER, I. R. (1986) Intensification, concentration and specialisation in agriculture in the case of the European Community, Geography, 71, 14-24.

BOWLER, I. R. and ILBERRY, B. W. (1989) The spatial restructuring of farm types in the English counties, 19761985, Tijdschrift voor Economische en Sociale Geografie, 80(5), 302-310.

CENTRAL STATISTICS OFFICE (1985) Estimated Output, Input and Income in Agriculture 1980-1984, Dublin.

CENTRAL STATISTICS OFFICE (1990) Estimated Output, Input and Income in Agriculture 1985-1990, Dublin.

COMMISSION OF THE EC (1985a) Perspectives for the Common Agricultural Policy, Brussels.

COMMISSION OF THE EC (1985b) A Future for European Agriculture, Brussels.

COMMISSION OF THE EC (1988) The Future of Rural Society, Luxembourg.

COMMISSION OF THE EC (1990) The Community's agricultural policy on the threshold of the 1990s, European File, 1/90, Brussels.

CONWAY, A. G. and O'HARA, P. (1987) Integrated Rural Development: a solution for rural areas?, in,The Restructuring of the Agricultural and Rural Economy, An Foras Taluntais, Dublin, 70-99.

CONWAY, A. G. (1990) Concluding reflections, in, Cuddy, M. et al. (eds.) Revitalising the Rural Economy: how can it be done?, University College Galway, Galway, 94-99.

COX, P. G., HIGGINS, J. and CUDDY, M. (1985) The Regional (Sub-national) Impact of the Common Agricultural Policy in Ireland, Report submitted to the Director General for Regional Policy, Commission of the European Communities, Brussels.
FINGLETON, W.A. (1988) Sheep Production, Proceedings of the Agricultural Economics Society of Ireland, 1987/ 88, 220-234.

GARDINER, M. J. and RADFORD, T. (1980) Soil Associations of Ireland and their landuse potential, An Foras Taluntais, Dublin.

GILLMOR, D. A. (1977) Agriculture in the Republic of Ireland, Akademiai Kiado, Budapest.

GILLMOR, D. A. (1987) Concentration of enterprises and spatial changes in agriculture of the Republic of Ireland, Transactions of the Institute of British Geographers, N.S., 12, 204-16.

GILLMOR, D. A. (1989) Agricultural Development, in, Carter, R.W.G. and Parker, A.J. (eds.) Ireland: $a$ Contemporary Geographical Perspective, Routledge, London, 171-200.

GOVERMENT OF IRELAND (1991) Programme for Economic and Social Progress, Stationery Office, Dublin.

HEAVEY, J. F. et al. (1981) Farm Management Survey 1981, Teagasc, Dublin.

HICKEY, B. and CONNOLLY, L. (1987) Returns and strategies for growth in the beef sector, in, The Restructuring of the Agricultural and Rural Economy, Teagasc, Dublin, 196-216.

HIGGINS, J. (1978) A shift and share analysis of changes in arable crop acreage and grazing livestock unit numbers in Irish counties (1954-73), Irish Journal of Agricultural Economics and Rural Sociology, 7, 63-87.

HORNER, A. A., WALSH, J. A. and WILLIAMS, J.A. (1984)Agriculture in Ireland: a census atlas, Department of Geography, University College, Dublin.

ILBERRY, B.W. (1990) The challenge of land redundancy, in, Pinder, D. (ed.) Western Europe - challenge and change, Belhaven Press, London, 211-225.

IRISH FARMERS ASSOCIATION (1989) Incomes and living standards on small farms in county Wexford, Irish Farmers Association, Dublin.

KEANE, T. (ed.) (1986) Climate, Weather and Irish Agriculture, AGMET, Dublin.

KELLEHER, C. and O'MAHONY, A. (1984) Marginalisation in Irish Agriculture, An Foras Taluntais, Dublin.

LEE, J. and McDONALD, E. (1989) Recent land use changes in Ireland, Farm and Food Research, 20(6), 15-17.

McSHARRY, R. (1991) The European Commission's Guidelines for the Reform of the Common Agricultural Policy, Brussels. 
MURPHY,E. (1988) Comparative advantage in dairying: an intranational study for Ireland, Irish Journal of Agricultural Economics and Rural Sociology, 13, 47-64.

SHEEHY, S. J. (1988) Irish Agriculture in the Nineties, The Irish Banking Review, Autumn, 21-32.

TEAGASC (1986) Irish Agriculture in Figures 1986, Teagasc, Dublin.

TEAGASC (1990a) Irish Agriculture in Figures 1990, Teagasc, Dublin.

TEAGASC (1990b) Incomes on Cattle Farms 1980-1990: an analysis and proposals for future viability, Teagasc, Dublin.
WALSH, J.A. and HORNER, A. A. ( 1984) Regional aspects of agricultural production in Ireland 1970-1980, Irish Geography, 17,95-101.

WALSH, J. A. (1986) Uneven Development of Agriculture in Ireland, Geographical Vienpoint, 14, 37-65.

WALSH, J. A. (1989) Enterprise substitution in Irish Agriculture: Sheep production in the 1980s, Irish Geographls, 22(2), 106-109.

WALSH, J.A. (1990) Regional implications of a Single Market European Community, Geographical Viewpoint, 18, 43-58. 